\title{
REPREZENTAREA CA PUTERE ÎN DREPTUL CIVIL ȘI SOCIETAR
}

Rezumat: Mecanismul juridic al puterii de reprezentare s-a bucurat încă din secolele trecute de o aplicabilitate însemnată datorită utilității sale incontestabile, atingând în prezent rangul de necesitate în rutina profesională și cotidiană. Cu toate acestea, majoritatea considerabilă a lucrărilor de specialitate care tratează acest subiect se concentrează pe analiza mandatului, ca izvor al puterii de reprezentare, fără a se apleca asupra naturii juridice a acestei prerogative. De aceea, scopul prezentului studiu, fără a avea pretenția exhaustivității, este acela de a radiografia specia reprezentării prin atentă raportare la genul său: puterea. Pragmatismul demersului nostru se evidențiază prin faptul că analiza reprezentării are loc în contextul materiilor în care este frecvent utilizată, anume dreptul civil comun, respectiv cel societar derogatoriu.

Cuvinte cheie: Putere, reprezentare, mandat, administrare, consimțământ, relativitatea efectelor, opozabilitate, administratorul societății, revocare.

* Avocat stagiar în Baroul Cluj, absolventă a Facultății de Drept din cadrul Universității BabeșBolyai Cluj-Napoca, contact ': https://orcid.org/00o0-0002-3667-6622; iuliaoprea182@gmail.com 


\title{
THE POWER OF ATTORNEY IN CIVIL AND COMMERCIAL LAW
}

\begin{abstract}
The power of attorney, as a judicial mechanism, has enjoyed a broad applicability for the past centuries due to its undeniable utility, reaching, at the moment, a level of necessity in the professional and casual routine. However, a great amount of the scientific literature that discuss this subject focus on the analysis of the mandate agreement, as a source for the power of attorney, without studying the legal nature of this prerogative. That is why the purpose of the present paper, avoiding any claim of completeness, is to scan the representation as a species, closely analysing its genus: the power. The pragmatism of our approach is revealed by the fact that the study of representation takes place in the context of the matters in which it is mostly used and that is the common civil law and the derogatory commercial law
\end{abstract}

Keywords: power, representation, mandate, administration, consent, the relativity of the effects, opposability, the manager of the company, withdrawal.

\section{Cuprins}

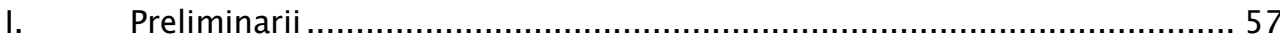

II. Dreptul comun al puterii de reprezentare ...................................... 58

A. Cntroverse doctrinare privind noțiunea de putere in sine...................... 59

1.Principiul relativități efectelor contractului vs. autonomia voinței reprezentantului. 63

2. Mecanismul concret de exteriorizare a consimțământului celui reprezentat 66

3. Obiectul puterii de reprezentare ..............................................6 68

4.Delimitarea puterii de reprezentare din cadrul mandatului de alte mecanisme juridice

B. Analiza reprezentării în cadrul raportului dintre societate și

administrator

1. Natura juridică și izvorul raportului dintre administrator și societate

2. Nearătarea calitătii de reprezentant.

3. Contractarea cu terțul după modificarea mandatului sau revocarea administratorului 82

4.Lipsa sau depășirea puterii de reprezentare. 86

III. Concluzii 88 


\section{Preliminarii}

Afluența și dinamica raporturilor juridice de la momentul actual fac aproape utopică perspectiva unei lumi în care nu există ideea de reprezentare în încheierea unui act. Fie că vorbim despre protecția oferită incapabililor, de „delegarea” sarcinii privind contractarea cu un terț unei alte persoane din lipsă de timp sau din dorința de a apela la profesioniști în materie de negocieri şi intermediere sau chiar de absoluta necesitate a existenței unui reprezentant în materie societară, încheierea actelor prin mandatar este la ordinea zilei.

$\mathrm{Cu}$ toate acestea, oricât de obișnuită ne apare posibilitatea exprimării consimțământului la încheierea unui act prin reprezentant, lucrurile s-au prezentat diferit în trecut, iar puterea de reprezentare a avut o evoluție sinuoasă de-a lungul istoriei. Astfel, deși conceptul de mandat a debutat în dreptul roman, noțiunea de reprezentare nu a fost acceptată, cel puțin în varianta sa perfectă, până la sfârșit de secol XVII. Cât despre eforturile doctrinare de a explica pe deplin ideea de reprezentare ... acestea nu s-au oprit până în zilele noastre, autorii recurgând la diverse teorii și efectuând conexiuni cu alte instituții de drept pentru a se înțelege întru totul acest mecanism.

Motivul pentru care un concept devenit deja atât de complex și de funcțional suscită încă ample dezbateri este însăși natura sa juridică greu de asimilat în dreptul civil: aceea de putere. Departe de a fi un demers pur teoretic, înțelegerea puterii ca prerogativă se impune datorită calității sale de gen față de specia reprezentării. Mergând un pas înainte, reprezentarea trebuie înțeleasă principial, în toate laturile sale și prin raportare la alte principii ale sistemului de drept în care se integrează. Aceasta deoarece întro societate care avansează într-un ritm alert, problemele ivite în fiecare 
moment necesită soluții care pot fi obținute numai pe cale „pretoriană” printro înțelegere deplină a mecanismului în esența lui. Nu în ultimul rând, față de integrarea puterii în sistemul dreptului civil, o nouă provocare este explicarea felului în care se comportă reprezentarea în raporturile de drept societar, o reprezentare care, prin natura domeniului, nu poate fi decât derogatorie.

Pentru aceste motive, prezenta lucrare își propune, fără a avea pretenția exhaustivității, de a analiza în mod critic anumite opinii doctrinare și de a expune un punct de vedere propriu referitor la puterea de reprezentare. În demersul nostru, am încercat să răspundem la câteva întrebări, credem noi, esențiale: ce este puterea ca prerogativă (A.1.), cum relaționează puterea de reprezentare cu anumite principii ale dreptului civil (aparent?) contrare (A.2.), care mecanisme din dreptul civil întemeiază conferirea puterii de reprezentare (A.3.), respectiv cum putem diferenția puterea de reprezentare de alte mecanisme asemănătoare (A.4.). Ducând discuția mai departe, am considerat oportun să analizăm cum se prezintă puterea de reprezentare în relaţia dintre administrator și societate, anume care este natura juridică a acestui raport (B.1.), respectiv care sunt derogările acestui tip de reprezentare faţă de dreptul comun (B.2. și urm.).

\section{Dreptul comun al puterii de reprezentare}

Conform definiției devenită deja notorie, puterea de reprezentare este mecanismul care conferă posibilitatea unei persoane, numită reprezentant, de a încheia un act juridic în numele și pe seama altei persoane, numită reprezentat, astfel încât efectele actului să se producă direct în patrimoniul 
reprezentatului ${ }^{1}$. Totuși, sub aparența simplității se ascunde o instituție complexă care, pe bună dreptate, a provocat discuții doctrinare ample cu privire la adevărata sa natură juridică.

\section{A. Cntroverse doctrinare privind noțiunea de putere in sine}

Înainte de toate, dacă am calificat reprezentarea ca fiind o putere, trebuie să aflăm cum anume se comportă o atare prerogativă. Astfel, poate exista tendința de a considera că în virtutea convenției dintre reprezentat și reprezentant, cel din urmă dobândește un drept subiectiv de a încheia acte juridice în numele și pe seama primului. Această concepție este una eronată, întrucât există o delimitare clară între un drept subiectiv şi o putere juridică conferită convențional, cu toate că cele două pot părea similare la o primă vedere. Diferențierea pare a consta în faptul că dreptul subiectiv aparține titularului său, indiferent de izvorul acestuia, iar puterea ar însemna exercitarea dreptului de către o altă persoană decât titularul² ${ }^{2}$ În concret, în ceea ce privește puterea de reprezentare, cel reprezentat are dreptul de a încheia acte juridice însă, prin intermediul unei convenții, acesta transmite reprezentantului puterea de a exercita el acest drept prin încheierea de acte juridice care să îl angajeze pe cel dintâi și care să producă efecte juridice direct în patrimoniul acestuia.

Explicațiile precedente rezumă concepția clasică privind puterea, ca prerogativă juridică, însă o atare perspectivă tinde să facă o confuzie între

\footnotetext{
${ }^{1}$ M. N. Costin, C.M. Costin, Dicționar de drept civil de la A la Z, ed. a 3-a actualizată și completată, Ed. Universul Juridic, București, 2019, p. 783.

${ }^{2}$ Gh. Piperea, Contractul de mandat, în Fl. A. Baias, E. Chelaru, R. Constantinovici, I. MACOvEI, Noul Cod civil. Comentariu pe articole, ed. a 2-a revizuită și adăugită, Ed. C.H. Beck, București, 2014, p. 2161.
} 
putere şi drept subiectiv și, în același timp, să nu ia în considerare faptul că nu numai exercitarea drepturilor subiective poate face obiectul puterii, ci și executarea unor obligații, efectuarea unei plăți. Astfel, s-au conturat anumite controverse doctrinare cu privire la natura juridică a puterii în sine.

În primul rând, ideea de putere se manifestă esențialmente în cadrul unui raport, a unei legături între persoane ${ }^{3}$, iar nu ca o prerogativă a unei persoane asupra unui bun. Practic, luând ca exemplu puterea de reprezentare, reprezentantul dobândește aptitudinea de a încheia acte juridice care produc efecte în patrimoniul reprezentatului, dar aceasta este consecința relației contractuale dintre cei doi și nu se explică printr-o prerogativă conferită reprezentantului asupra bunurilor din patrimoniul reprezentatului ${ }^{4}$.

În al doilea rând, potrivit unei opinii ${ }^{5}$, puterea este în același timp atât un drept, cât și o obligație ${ }^{6}$. Într-adevăr, puterea se diferențiază de dreptul potestativ prin faptul că nu se rezumă la simpla facultate a titularului prerogativei de a o exercita, ci implică și anumite îndatoriri față de constituitorul ei (în cazul puterii de reprezentare, față de cel reprezentat) precum diligența în exercitarea prerogativelor conferite, evitarea conflictului de interese ori datoria de a îndeplini împuternicirea oferită ${ }^{7}$. Cu toate acestea, nu putem reduce esența puterii la acest aspect, căci într-o astfel de situație nu

3 R. Rizolu, Oglinzi paralele: Este puterea de reprezentare o veritabilă putere? în RRDP nr. 2/2019, p. 97.

4 O părere contrară: P. Malaurie, L. Aynès, P. Stoffel-Munck, Drept civil. Obligațiile, traducere de D. DĂNișor, ed. a 3-a, Ed. Wolters Kluwer, București, 2009., p. 440.

5 R. DINCĂ, Contracte civile speciale în noul Cod civil. Note de curs, Ed. Universul Juridic, București, 2013, p. 226.

${ }^{6}$ Contra: R. RIzoIU, op.cit., în RRDP nr. 2/2019, p. 71, nota de subsol nr. 16. Autorul susține că este imposibil ca o prerogativă să fie în același timp atât o putere, cât și un drept și o obligație. 7 Această ultimă datorie devine obligație contractuală în cazul contractului de mandat, însă rămâne o îndatorire intrinsecă oricărei puteri. 
ar mai exista deosebire între putere și dreptul subiectiv inclus într-un raport sinalagmatic, iar o atare confuzie nu poate fi admisă.

Astfel, acceptăm existența unor îndatoriri în sarcina celui împuternicit, însă acestea au o natură juridică specială care își găsește explicația în faptul că orice putere implică o restrângere corelativă a libertăţii celui care conferă acea putere. Având în vedere dificultatea cu care dreptul civil acceptă restrângerea libertății unei persoane în detrimentul celeilalte, dobândirea puterii atrage după sine anumite datorii, însă acestea nu sunt autonome şi nici nu definesc în sine puterea, ci sunt intrinseci acesteia. Pe cale de consecință, aceste datorii se diferențiază de obligațiile corelative unui drept de creanță întrucât în caz de neexecutare sau executare necorespunzătoare nu atrag angajarea răspunderii civile ordinare a titularului puterii, ci sancțiuni specifice precum lipsirea de efecte a actului încheiat cu terțul în ceea ce îl privește pe reprezentat sau anularea actului încheiat de reprezentantul aflat în conflict de interese în cazul puterii de reprezentare ${ }^{8}$.

În al treilea rând, cu privire la conduita celui care conferă puterea, s-a opinat $^{9}$ că acesta nu ar mai putea să exercite el însuşi prerogativele cu care la împuternicit pe titularul puterii. Într-adevăr, acest lucru este aplicabil în anumite cazuri, precum cel al reprezentării legale a cărei rațiuni este tocmai incapacitatea constituitorului de a încheia singur actul. În schimb, în cazul reprezentării convenționale, aceste susțineri nu mai corespund $^{10}$. Reprezentatul își menține prerogativele al căror titular este, iar în

\footnotetext{
${ }^{8}$ V. STOICA, Despre puterea de reprezentare, în RRDP nr. 2/2019, p. 32.

9 Ibidem, p. 31.

10 N. Mathey, Représentation, Rép. civ. Dalloz, avril 2007, pg. 53: „la représentation conventionnelle laisserait au représenté l'exercice de ses droits, sous réserve de son devoir de loyauté envers son représentant, précise le projet."
} 
momentul constituirii puterii le dedublează ${ }^{11}$, oferind „copia” acestora reprezentantului. Însuși termenul de reprezentare conduce la această concluzie, dacă luăm în considerare sensul platonic ${ }^{12}$ al termenului.

În ciuda conflictului doctrinar analizat, există un element majoritar ${ }^{13}$ acceptat ca fiind definitoriu pentru termenul de putere în dreptul civil, anume faptul că titularul puterii acționează în interesul (cel puțin parțial) al celui care i-a conferit respectiva putere, iar nu în interes propriu precum în cazul unui drept subiectiv. Acest aspect este esențial pentru corecta calificare a puterii și scoate în evidență o componentă altruistă a acestui tip de prerogativă $\breve{1}^{14}$. In acest sens trebuie analizate îndatoririle explicate în paragraful anterior: odată cu obținerea puterii, cel care o primește este dator să respecte limitele acesteia și să acționeze conform scopului pentru care i-au fost acordate, anume să le exercite în interesul celui care i-a „transmis” puterea. Nesocotirea acestor îndatoriri poartă denumiri specifice, anume depășirea puterilor conferite, respectiv deturnarea sau abuzul de putere. Acest din urmă caz se referă la ipoteza în care titularul puterii acţionează în limitele conferite, însă în interes propriu sau al unui terț ${ }^{15}$, încălcând scopul conferirii respectivei puteri. În ceea ce privește puterea de reprezentare, cazuri expres

\footnotetext{
${ }^{11}$ R. RIzoIU, op.cit., p. 112.

${ }^{12}$ Ideea de reprezentare a realității prin dedublarea ei a fost exprimată de Platon în Mitul Peșterii inclus în lucrarea Republica.

${ }^{13} \mathrm{Cu}$ excepția părerii exprimate în: R. RızoIU, op.cit., p. 103, care susține faptul că răspunderea reprezentantului pentru deturnare de putere se datorează existenței puterii în sine, iar nu nerespectării interesului reprezentatului.

${ }^{14}$ M. Avram, Nimeni nu vine la Tatăl decât prin Mine: o incursiune în logica autorității și a puterii în dreptul privat, În RRDP nr. 2/2019, p. 59. Autoarea extrapolează discuția analizată și acordă un statut mesianic reprezentantului ca titular al puterii care acționează ca mijlocitor între om şi divinitate.
}

15 N. MatheY, op.cit., pg. 58. 
reglementate de abuz de putere reprezintă conflictul de interese, contractul cu sine însuşi, respectiv dubla reprezentare (art. 1303 și 1304 C.civ.), situații în care sancțiunea unei asemenea conduite este nulitatea relativă a actului astfel încheiat ${ }^{16}$.

Pe cale de consecință, distanțându-ne de concepția clasică privind reprezentarea, precum şi de orice confuzii între putere și drept sau obligație, suntem de părere că reprezentarea se prezintă într-adevăr ca o veritabilă putere juridică, prerogativă care se relevă ca o legătură între persoane, incluzând în mod inerent anumite îndatoriri ce nu pot fi confundate cu obligațiile corelative unui drept subiectiv. În acelaşi timp, puterea nu se transmite, ci se conferă, întrucât titularul său păstrează prerogativele conferite și după acest moment, în timp ce acela care le dobândește acţionează invariabil în interesul, cel puțin parțial, al celui dintâi.

1. Principiul relativității efectelor contractului vs. autonomia voinței reprezentantului

În ceea ce privește puterea de reprezentare, de-a lungul timpului a fost analizată în doctrină ipoteza de a fi considerată ca o excepție de la principiul relativității efectelor contractului enunțat în art. 1280 C.civ. și exprimat prin adagiul res inter alios acta, aliis neque nocere, neque prodesse potest. Acesta prevede în esență faptul că părțile unui contract sunt singurele ținute de obligațiile izvorâte din acesta. Ca atare, s-a pus întrebarea dacă reprezentatul,

\footnotetext{
16 Autorul citat în nota precedentă consideră că sancțiunea deturnării de putere nu ar trebui să fie anularea actului astfel încheiat, ci menținerea efectelor sale cu angajarea răspunderii titularului puterii față de cel care a conferit-o. Cu toate acestea, terții de bună-credință ar putea fi protejați prin aplicarea teoriei aparenței. În Codul civil român nu este necesară recurgerea la teoria aparenței, art. 1303 stipulând expres aplicabilitatea sancţiunii doar în cazul lipsei buneicredințe a terțului contractant.
} 
care nu încheie personal contractul, dar care este ținut de obligațiile asumate de reprezentant prin contractarea cu terțul, sfidează regula relativităţii actelor juridice $^{17}$. Părerea majoritar acceptată în doctrină ${ }^{18}$ este că reprezentarea respectă pe deplin principiul analizat, întrucât cel reprezentat exprimă consimțământul la încheierea contractului cu terțul și devine parte în acesta, iar lipsa lui fizică de la încheierea actului este irelevantă deoarece importantă este prezența lui juridică, consimțământul exprimat printr-un act juridic anterior încheiat cu reprezentantul. Vom încerca să detaliem.

Astfel, s-ar părea că reprezentantul „transportă” voința juridică a reprezentatului, consimțământul său la încheierea actului cu terțul, prin intermediul puterii de reprezentare conferite $^{19}$. Aceasta este totuşi o perspectivă care suportă critici. Reprezentantul nu poate fi considerat un simplu alter ego al reprezentatului, ci își exprimă propria voință și beneficiază de autonomie în raport cu voința reprezentatului ${ }^{20}$. Altfel spus, aşa cum într-un mod mai plastic s-a exprimat un autor ${ }^{21}$, reprezentantul are un cap

17 În acest sens: N. MATHEY, op.cit., pg. 21. Autorul citat este de părere că reprezentarea este o derogare de la dreptul comun în privința relativității efectelor actului juridic. (i.e. „imputation dérogatoire"); P. LE Tourneau, Mandat, Rép. civ. Dalloz, juin 2011, pg. 324.

18 H. Dumitrescu, Reprezentarea, Noul Cod civil. Comentariu pe articole, ed. a 2-a revizuită şi adăugită, Ed. C.H. Beck, Bucureşti, 2014 p. 1444; I. Reghini, Ș. DiACONESCU, P. VASILESCU, Introducere în dreptul civil, p. 625; P. VASILESCU, Drept civil. Obligații, Ed. Hamangiu, București, 2012, p. 473. Ultimul autor citat exprimă o opinie mai exigentă, considerând că nu există decât excepții aparente de la principiul relativității efectelor contractului.

19 În acest sens: R. RızOIU, op.cit., p. 114. Autorul consideră că reprezentantul nu face decât să ducă la îndeplinire ordinele reprezentatului, iar reprezentarea nu este o veritabilă putere, ci doar un mijloc de prelungire a voinței reprezentatului.

20 P. Le Tourneau, op.cit., pg. 76. Cu toate că autorul menționează inițial (pg. 65) că reprezentantul este un alter ego al reprezentatului, ulterior revine asupra acestei afirmații și include autonomia reprezentantului printre consecințele esențiale ale puterii de reprezentare. ${ }^{21}$ P. Malaurie, L. Aynès, P. Gautier, Contractele speciale, traducere de D. DĂNișor, ed. a 3-a, Ed. Wolters Kluwer, Bucureşti, 2009, p. 263. 
care gândește și o voință care are independența sa. În caz contrar, nu ar mai putea fi vorba despre o veritabilă putere de reprezentare ci, eventual, am fi în prezența unui contract de antrepriză sau a unui contract individual de muncă ${ }^{22}$.

Desigur, reprezentatul poate trasa anumite limite destul de rigide în interiorul cărora reprezentantul să își exercite puterea, dar chiar în cazul mandatului conferit în termeni restrictivi, reprezentatul nu face decât să traseze anumite direcții, să indice finalitatea la care reprezentantul ar trebui să ajungă prin contractarea în interesul primului, ceea ce nu conduce în niciun caz la anihilarea autonomiei reprezentantului, a libertăţii acestuia de a alege mijloacele efective de îndeplinire a finalității dorite de reprezentat. Strict din această perspectivă, puterea de reprezentare poate fi oarecum asemănată cu mecanismul de funcționare al directivelor din Dreptul Uniunii Europene. Astfel, organele Uniunii (i.e. reprezentatul) emit o directivă prin care impun o anumită finalitate la care statele membre (i.e. reprezentantul) trebuie să ajungă prin reglementări interne care să se aplice cetățenilor (i.e. terți contractanți), însă maniera efectivă prin care se ajunge la acea finalitate stă în libertatea de decizie a statelor membre, atâta timp cât finalitatea este atinsă și scopul directivei (i.e. în raportul de reprezentare: interesul reprezentatului) este respectat. În mod evident, raporturile de drept public sunt incompatibile cu

22 P. LE TOURnEAU, op.cit., pg. 77. Cu toate acestea, autorul susține că este posibilă o oarecare subordonare a mandatarului față de mandant, fapt care ar justifica răspunderea comitentului pentru fapta prepusului în sarcina celui din urmă (pg. 78).

\section{5}


mecanismul de funcționare al reprezentării convenționale dezvoltat în prezenta lucrare, iar analogia anterioară are rol pur explicativ.

2. Mecanismul concret de exteriorizare a consimțământului celui reprezentat

Odată acceptat faptul că se disting două voințe, cea a reprezentantului și cea a reprezentatului, ne rămâne să analizăm modul de funcționare și natura juridică a acestora. Astfel, s-a exprimat opinia ${ }^{23}$ potrivit căreia: „voința juridică a reprezentatului şi voința juridică a reprezentantului, reunite în contractul de reprezentare, sunt diferite nu numai una față de alta, ci și față de voința reprezentatului, obiectivată în actul juridic unilateral, care este primul element al puterii de reprezentare , dar şi față de voința reprezentantului, aflată mai întâi în stare virtuală, ca al doilea element al puterii de reprezentare, iar apoi obiectivată în momentul încheierii actului juridic în numele și pe seama reprezentatului." (s.n.) În contextul precizării relevanței teoretice a logicii prezentate, autorul citat face trimitere la ideea de separație și abstractizare ${ }^{24}$, concepte recurente în doctrina germană recentă cu privire la reprezentare ${ }^{25}$.

Din rândurile citate, înțelegem că în optica autorului, lucrurile se prezintă în maniera următoare: puterea de reprezentare are ca izvor contractul (încheiat ca urmare a exprimării consimțământului fiecăreia dintre

\footnotetext{
23 V. STOICA, op.cit., p. 43-45.

24 V. STOICA, op.cit., p. 45 și 46.

25 În același sens: D.A. POPESCU, Abstracțiunea reprezentărï voluntare şi funcția circulatorie a actelor, în RRDP nr. 2/2019, p. 245 și urm. Trebuie menționat totuși că autorul susține această perspectivă prin raportare la doctrina și legislația germane, însă afirmă în mod critic că aceasta nu poate fi aplicată reprezentării din sistemul românesc, având în vedere modul în care acest mecanism este reglementat în Codul civil.
} 
părți), însă aceeași putere de reprezentare „încapsulează” alte două voințe: cea a reprezentatului, luând forma unui act unilateral, respectiv cea virtuală a reprezentatului, care va „prinde contur” abia la momentul încheierii contractului cu terțul. Cu toate că nu putem nega originalitatea unei astfel de perspective, vom expune în continuare contraargumentele noastre.

Astfel, chiar dacă am accepta că puterea de reprezentare înglobează o altă manifestare de voință a reprezentatului decât cea exprimată la încheierea contractului de mandat, această manifestare nu poate îmbrăca haina unui veritabil act unilateral în sensul art. 1324 C. civ. din simplul motiv că mai are nevoie de o voință (chiar virtuală), alta decât cea a emitentului pentru a produce efecte juridice.

Pe de altă parte, considerăm că teoria nu prezintă interes practic, întrucât eventualele mecanisme pe care le-ar putea explica pot fi mai lesne înțelese prin raportare la alte instituții care se integrează natural în sistemul civil românesc. $\mathrm{Cu}$ alte cuvinte, un anumit concept poate fi înțeles pe deplin în cadrul sistemului juridic din care a luat naștere. Preluarea aceluiași concept de către un sistem străin este eficientă, fără a complica inutil, numai în măsura în care instituţiile proprii ale celui din urmă sunt insuficiente pentru a oferi o explicație satisfăcătoare cu privire la modalitatea de funcționare a unui mecanism sau în ipoteza în care mecanismul în sine a fost la rândul său importat din același sistem din care provine și conceptul preluat.

Un exemplu ar putea fi edificator: în ipoteza în care puterea de reprezentare încetează, iar terțul contractant s-a aflat într-o eroare legitimă cu privire la existența acesteia la momentul încheierii contractului, puterea de reprezentare va produce efecte față de acesta, ca și cum nu ar fi încetat niciodată. Această soluție este însă explicată prin prisma inopozabilității 
încetării față de terțul contractant de bună-credință ${ }^{26}$, astfel că nu este necesară recurgerea la teoria separației dintre raportul intern și cel extern al reprezentării care să justifice o oarecare supraviețuire parțială a acesteia.

De asemenea, s-ar putea încerca utilizarea premisei formulate pentru a exclude puterea de reprezentare din aria excepțiilor de la principiul relativității efectelor contractului, însă am prezentat opinia noastră cu privire la acest subiect în secțiunea precedentă, astfel că nu vom reveni asupra ei.

Pe cale de consecință, considerăm că recurgerea la multiple acte juridice pentru a explica aptitudinea reprezentantului de a utiliza prerogativele sale de reprezentare ne transpare ca inutilă, în condițiile în care conferirea acestei puteri este tocmai efectul principal al contractului de mandat la care ambele părți au consimțit.

\section{Obiectul puterii de reprezentare}

Codul civil reglementează expres faptul că obiectul puterii de reprezentare, în contractul de mandat, este încheierea de acte juridice unilaterale sau contracte, de unde reiese, în mod evident, că actele materiale, faptele juridice licite sau, cu atât mai mult, ilicite ies din domeniul de aplicare al reprezentării, nefiind compatibile cu aceasta. Există totuşi voci ${ }^{27}$ care afirmă că este posibilă săvârşirea de fapte juridice şi acte materiale prin reprezentare şi, mai mult decât atât, reprezentatul răspunde pentru faptele ilicite săvârșite de către reprezentant în executarea împuternicirii. Unul dintre argumentele aduse în favoarea acestei concepții este existența în dreptul civil

\footnotetext{
${ }^{26}$ Pentru o dezvoltare a acestei premise cu aplicație în domeniul societar, a se vedea infra: pg. II.B.3.

27 Ibidem, pg. 18-20: „La limitation de la représentation aux actes juridiques est, sans doute, le résultat d'une transposition hâtive et injustifiée d'une doctrine allemande".
}

\section{8}


a posesiei corpore alieno (i.e. exercitarea posesiei „prin intermediul” unui detentor precar, precum în cazul locațiunii sau comodatului). Într-adevăr, sau formulat opinii ${ }^{28}$ conform cărora detentorul precar ar juca rolul unui reprezentant al posesorului, întrucât acesta ar dobândi puterea de a exercita elementul corpus care este esențialmente o chestiune de fapt și care poate fi valorificat doar prin acte materiale.

$\mathrm{Cu}$ toate acestea, nu putem fi de acord cu această perspectivă. Mecanismul de funcţionare al posesiei corpore alieno se aseamănă cu cel al reprezentării convenționale, dar nu se identifică cu acesta, iar reglementările legale aplicabile acestora nu coincid, normele referitoare la posesie și detenție precară fiind regăsite în art. 916 și urm. din C.civ. În plus, detentorul precar, practic, exercită temporar posesia, la fel cum fiduciarul dobândește temporar dreptul de proprietate, astfel că aceștia acționează în nume propriu, iar nu în numele celor de la care au obținut respectivele prerogative, astfel că nu poate fi vorba nici măcar de o pseudo-reprezentare.

De asemenea, în doctrina româneasc $\breve{a ̆}^{29} \mathrm{~s}$-a admis posibilitatea săvârşirii faptelor juridice licite prin reprezentant, însă considerăm că teoria este una eronată. Vom trata faptele succesiv. În primul rând, pentru a putea discuta despre posibilitatea săvârşirii unei plăți nedatorate prin mandatar, trebuie să analizăm natura juridică a plății, adică să stabilim dacă plata este un act sau un fapt juridic. Există controverse doctrinare în acest sens, însă autorii tind, ca regulă, să considere că plata are o natură juridică complexă, ce ține atât de convenție, cât și de faptul juridic ${ }^{30}$ : solvens execută un fapt animat

\footnotetext{
28 A. TAMBA, Posesorul și detentorul - o ipoteză de reprezentare, în RRDP nr. 2/2019, p. 375. ${ }^{29}$ H. Dumitrescu, Reprezentarea, în Fl. A. Baias, E. Chelaru, R. Constantinovici, I. Macovei, op.cit., p. 1445 .

30 P. Malaurie, L. Aynès, P. Stoffel-Munck, op.cit., p. 621.
}

69 
de o intenție de a stinge obligația (animus solvendi), iar accipiens acceptă intenționat că prin executarea faptului se stinge creanța sa ${ }^{31}$. Se consideră, deci, că această componentă volițională a plății poate justifica executarea acesteia prin mandatar. Cu toate acestea, plata nedatorată, ca fapt juridic licit, implică în mod necesar ca solvens să fie în eroare scuzabilă, adică să considere în mod justificat, deşi eronat, că există un debit şi efectuează plata pentru stingerea debitului. Or, în acest sens, eroarea este incompatibilă cu mecanismul reprezentării. Dacă solvens dorește să facă o plată prin reprezentant, fiind în eroare, puterea de reprezentare conferită se referă la actul juridic al plății, iar faptul juridic care dă naștere obligației de restituire se referă la eroarea asupra debitului, cele două mecanisme (reprezentarea și faptul juridic licit) funcționând concomitent, dar nu interdependent.

În al doilea rând, autorul citat susține posibilitatea săvârşirii unei îmbogățiri fără justă cauză prin reprezentant atunci când acest fapt rezultă din anumite acte juridice încheiate prin mandatar. Nici această idee nu poate fi acceptată întrucât, din nou, sunt suprapuse în aceeași împrejurare două mecanisme juridice complet distincte, anume: dacă cel însărăcit dă mandat unei persoane să încheie un act juridic în numele şi pe seama lui, iar în urma actului se produce o îmbogățire fără justă cauză, temeiul obligației de restituire rămâne faptul juridic al îmbogățiiii, căruia legea îi conferă obligativitate, iar nu contractul de mandat care este pur circumstanțial.

În ceea ce privește gestiunea de afaceri, dacă există o conferire a puterii de reprezentare gerantului, nu mai poate fi vorba de gestiune de afaceri, ci discutăm despre un veritabil mandat. Aplicarea în cazul gestiunii de afaceri a regulilor de la mandat, în cazul ratificării acesteia de către gerat,

${ }^{31}$ P. VASIlescu, op.cit., p. 74 . 
nu schimbă această chestiune ${ }^{32}$. Este adevărat că, dacă gerantul efectuează acte juridice pentru gerat prin reprezentant, actul respectiv poate lega terțul, care a contractat cu mandatarul. de gerat dacă gerantul nu a acționat în nume propriu. Totuşi, în speță, există două raporturi obligaționale distincte: primul ia naștere dintr-un fapt juridic, anume gestiunea de afaceri realizată de gerant, iar al doilea izvorăşte din contractul de mandat încheiat de către gerant, însă acesta din urmă are ca obiect tot încheierea de acte juridice de către mandatar în numele și pe seama gerantului aflat în „reprezentarea” geratului. Chiar dacă, faptic, aceste operațiuni ar avea ca obiect aceeași situație și chiar în cazul în care efectele acestora s-ar produce direct în patrimoniul geratului, din punct de vedere juridic sunt două realităţi și mecanisme distincte. Pe cale de consecință, relațiile dintre mandatar si gerant vor fi guvernate de contractul de mandat încheiat de aceștia, în timp ce în cadrul relațiilor dintre gerant și gerat, respectiv a celor dintre gerat și terț își vor găsi aplicabilitatea regulile din materia gestiunii de afaceri ca fapt juridic.

În concluzie, suntem de părere că încheierea de acte juridice reprezintă domeniul predilect al puterii de reprezentare, actele materiale și faptele juridice nefiind compatibile cu acest mecanism ${ }^{33}$. Aceasta este și diferența principală dintre contractul de mandat și cel de antrepriză, al cărui obiect vizează efectuarea de acte materiale în favoarea altei persoane. Totuși, contractul de mandat poate implica efectuarea unor acte materiale, însă

\footnotetext{
$3^{2}$ V. STOICA, op.cit., pp. 34-35. Autorul susține că în cazul gestiunii de afaceri putem discuta despre reprezentare, însă este vorba de o „reprezentare fără putere”, întrucât se produc anumite efecte specifice reprezentării în lipsa conferirii puterii prin convenție. $\mathrm{Cu}$ alte cuvinte, „raportul extern al reprezentării se naște fără a exista și un raport intern”.

33 P. LE TOURneAu, op.cit., pg. 72-75.
} 
acestea trebuie să fie cu titlu accesoriu ${ }^{34}$ raportat la obligația principală din contract, aceea de a încheia anumite acte juridice în numele și pe seama cocontractantului. $\mathrm{Nu}$ în ultimul rând, trebuie precizat faptul că excedă domeniului reprezentării actele juridice cu un puternic caracter personal, precum testamentul sau actele referitoare la căsătorie ${ }^{35}$.

4. Delimitarea puterii de reprezentare din cadrul mandatului de alte mecanisme juridice

În Codul civil, există numeroase instituții care se apropie până aproape de identificare cu puterea de reprezentare generată în contractul de mandat însă, în fiecare caz, pot fi semnalate anumite diferențe care să ne dirijeze în găsirea regimului juridic aplicabil. Pentru a identifica respectivele deosebiri, vom analiza în continuare regimul juridic al administrării bunurilor altuia, al fiduciei, precum şi al intermedierii prin comparare cu puterea de reprezentare din contractul de mandat.

Astfel, Codul civil reglementează administrarea bunurilor altuia (nu întâmplător) în cadrul Cărții a III-a referitoare la bunuri. Acest contract este unul complex care reunește, în esență, prerogative specifice mandatului și antreprizei, în sensul că, în conformitate cu art. 792 C.civ., administratorul poate (și are îndatorirea) să efectueze acte juridice și materiale cu privire la unul sau mai multe bunuri, la o masă patrimonială sau chiar la un patrimoniu în beneficiul titularului acestora în urma împuternicirii conferite de către cel din urmă.

34 Ibidem, pg. 73: „Au fond, tout mandat comporte de pareils actes [des actes matériels], quand ce ne serait que l'apposition d'une signature”.

$35 \mathrm{Cu}$ toate că anumiți suverani francezi (e.g. Louis XVI sau Napoleon I) obișnuiau să încheie căsătorii prin reprezentant, atunci când partenerii erau străini. (P. le TOURNEAU, op.cit., pg. 72). 
Ca atare, prin contractul de administrare, administratorul dobândește putere de reprezentare. Însă care este relația dintre normele care reglementează acest contract şi regulile referitoare la mandat (art. 2009 şi urm. C.civ.)? În doctrină, s-a exprimat părerea ${ }^{36}$ conform căreia mandatul ar reprezenta o formă specială de administrare a bunurilor altuia, astfel că normele referitoare la mandat ar avea caracter derogatoriu față de cele de la administrare şi ar putea fi completate de cele din urmă. Această perspectivă se bazează pe dispozițiile art. 792 alin. (3) și ale art. 794 C.civ.

Totuşi, avem anumite rezerve faţă de această viziune şi vom expune o opinie contrară. Regulile aferente puterii de reprezentare (art. 1295 și urm.) constituie dreptul comun în materie de reprezentare şi se aplică, de principiu, oricărui contract prin care se conferă astfel de prerogative. Contractul de mandat este un contract special, astfel că beneficiază de o reglementare specială aplicabilă acestui tip de convenție, completându-se în mod corespunzător cu regimul general al reprezentării. În acelaşi timp, contractul privind administrarea bunurilor altuia reprezintă un contract complex care, după cum am afirmat anterior, reunește reguli aferente mandatului şi antreprizei, formând un mecanism distinct, special față de regimul aplicabil celor două contracte, putând fi, la rândul lui, completat de regulile acestor contracte ${ }^{37}$ și de dreptul comun al reprezentării în cazul încheierii de acte juridice în numele şi pe seama beneficiarului. Articolul. 792 alin. (3) și art. 794 C. civ se referă la alte ipoteze de administrare a bunurilor

${ }^{36}$ R. Constantinovici, A.M. Mitu, Administrarea bunurilor altuia în Fl. A. BAias, E. Chelaru, R. Constantinovici, I. Macovei, op.cit., p. 900; I. SFERdian, Efectele expirării mandatului administratorului unei societăți, în RRDP nr. 2/2019, p. 147.

37 R. Constantinovici, A.M. Mitu, Administrarea bunurilor altuia în Fl. A. BAias, E. ChelaRU, R. Constantinovici, I. Macovei, op.cit., p. 899. Tocmai autoarele opiniei combătute fac trimitere la art. 2013 C.civ. care completează regimul administrării. 
altuia, precum cazul tutorelui (art. 142 C.civ.), nicidecum la contractul special de mandat.

Astfel, atât contractul de mandat cât și administrarea bunurilor altuia conferă putere de reprezentare, însă contractul de mandat reprezintă cadrul clasic de manifestare al acestui tip de putere, nefiind vorba de o aplicare derogatorie a regimului administrării. În plus, considerăm că puterea de reprezentare din cadrul administrării are o natură juridică diferită de reprezentarea de drept comun, fiind, astfel, în sine, derogatorie. Am explicat anterior ${ }^{38}$ faptul că puterea de reprezentare aferentă mandatului se relevă ca o legătură între persoane. În schimb, puterea de reprezentare conferită în cadrul administrării bunurilor altuia apare ca o legătura a unei persoane (i.e. administratorul) cu anumite bunuri sau cu un patrimoniu ${ }^{39}$. Astfel se explică independența sporită a administratorului, în opoziție cu îngrădirile mai accentuate ale mandatarului ${ }^{40}$, administratorul efectuând orice acte consideră de cuviință pentru conservarea (în cazul administrării simple) sau sporirea valorii economice (în cazul administrării depline) a bunului sau patrimoniului administrat. În același sens, puterea de reprezentare aferentă administrării încetează în cazul stingerii dreptului beneficiarului asupra bunurilor administrate (art. 846 lit. a C.civ.), ceea ce evidențiază caracterul de legătură a unei persoane cu un bun în cazul acestui tip de reprezentare. $\mathrm{Ca}$ atare, nu numai contractul privind administrarea

${ }^{38}$ A se vedea: supra, pg. II.A.

39 I. SFERDIAN, op.cit., p. 146: „ (...) o putere asupra bunurilor altuia”.

$4^{0}$ R. RizoIU, op.cit., p. 114. Această diferențiere este motivul pentru care autorul consideră că puterea de reprezentare din mandat nu este o veritabilă putere, în timp ce reprezentarea aferentă administrării are această calitate. 
bunurilor altuia, ci și puterea de reprezentare în sine aferentă acestui contract, constituie cazuri speciale şi derogatorii, iar nu dreptul comun în materie.

De asemenea, ar putea apărea confuzii între reprezentare şi fiducie, întrucât în ambele cazuri reprezentantul, respectiv fiduciarul, încheie acte juridice în interesul altei persoane (i.e. în cazul fiduciei, în interesul beneficiarului). $\mathrm{Cu}$ toate acestea, cele două mecanisme nu pot fi confundate deoarece în cazul fiduciei operează un transfer al drepturilor constituitorului în favoarea fiduciarului, caracterul temporar al acestuia nefiind relevant. Astfel, în momentul în care contractează cu un terț în interesul beneficiarului, fiduciarul devine parte în contract şi acționează în nume propriu, iar efectele contractului se produc în masa patrimonială fiduciară care se află în patrimoniul acestuia. Se poate observa, aşadar, o distincție clară între aceste mecanisme juridice, mandatarul acționând în numele şi pe seama mandantului, în timp ce fiduciarul acționează în nume propriu, în calitate de titular al dreptului în legătură cu care contractează.

În fine, în ceea ce privește contractul de intermediere, acesta se diferențiază de mandat prin faptul că nu conferă putere de reprezentare, ci presupune doar obligația asumată de intermediar de a pune în legătură două persoane între care urmează să se încheie un contract. Cu toate acestea, există în doctrina şi jurisprudența franceză anumite controverse în privința naturii juridice a raportului dintre agentul imobiliar și clientul său. Un autor ${ }^{41}$ consideră că natura juridică unui asemenea contract depinde de atribuțiile concrete ale agentului imobiliar. Astfel, dacă acesta poate negocia, administra anumite bunuri sau i se conferă expres dreptul de a încheia contractul, vom fi indiscutabil în prezența unui mandat, chiar dacă agentul efectuează în mod

${ }^{41}$ P. Le Tourneau, op.cit., pg. 69. 
accesoriu anumite acte materiale. În schimb dacă singura obligație a agentului este de a găsi potențiali cumpărători și de a-i pune în legătură cu vânzătorul, vom discuta despre o simplă intermediere. Aceste susțineri sunt în acord cu art. 2102 din C.civ. conform căruia puterea de reprezentare este conferită prin contractul de intermediere doar dacă se stipulează expres în acest sens. Autorul constată, totuşi, că jurisprudența a admis calificarea ca mandat a unui contract care limitează misiunea agentului la contactarea potențialilor cumpărători, opinie pe care, în mod corect, o combate considerând că această calificare este eronată, iar un atare contract nu va permite agentului să încheie vânzarea în numele şi pe seama clientului, în caz contrar, operând regulile privind contractarea în lipsa puterii de reprezentare.

\section{B. Analiza reprezentării în cadrul raportului dintre societate și administrator}

În cele ce urmează vom prezenta, succint, care sunt elementele de specificitate ale mandatului din dreptul societar, reglementat în principal de Legea 31/1990, prin raportare la mandatul de drept comun. Ca atare, ne vom concentra atenția asupra naturii juridice a acestuia şi a eventualelor diferențieri față de cel din urmă, fără a analiza însă chestiunile legate de atribuțiile specifice ale organelor de administrare aferente anumitor forme de organizare a societăților. În acest sens, prin „administrator” ne vor referi, în continuare, la organul care exercită prerogativa de administrare a unei societăți, având în același timp putere de reprezentare ${ }^{42}$, indiferent de denumirea concretă a acestuia conferită de terminologia dreptului societar.

\footnotetext{
42 Există cazuri în care unii dintre administratorii unei societăți sunt doar gestionari ai patrimoniului social, fără a avea și puterea de reprezentare a societății, în ipoteza în care actul constitutiv prevede în acest sens.
} 
1. Natura juridică și izvorul raportului dintre administrator și societate

Astfel, având în vedere că art. 218 C.civ. face referire la puterea de reprezentare a organelor de administrare, o primă problemă care se cuvine a fi analizată se referă la natura juridică a acestei reprezentări. Pe de o parte, sar putea considera că este vorba despre o reprezentare legală, dat fiind că societatea nu își poate exercita capacitatea de exercițiu decât prin administratorii săi ${ }^{43}$, aceasta fiind o dispoziție legală cu caracter imperativ (art. 209 C.civ.). Astfel, precum în cazul reprezentării legale a persoanelor fizice lipsite de capacitate de exercițiu, administratorul exercită, în raporturile cu terții, drepturile și obligațiile societăţii.

Pe de altă parte, ar exista argumente şi în favoarea unei reprezentări convenționale, având în vedere faptul că rolul de administrator al societății se naşte ca urmare a unei convenții care stabilește condițiile de desfăşurare ale raporturilor dintre administrator și societate, reglementând inclusiv limitele puterii de reprezentare. Într-adevăr, legea prefigurează anumite elemente ale acestui raport însă contractul, ale cărui dispoziții sunt incluse, de regulă, în actul constitutiv, rămâne principalul izvor al relațiilor dintre organ și societate. Datorită caracterului eclectic al acestui raport juridic, a fost utilizat, în doctrina dreptului societar, termenul de „mandat legal”44.

43 S. Bodu, Organul administrativ şi reprezentarea legală a societății comerciale (I), extras din RRDA nr. 6/2017, p. 1, publicat online la data de 17.09.2018, la adresa https://www.universuljuridic.ro/organul-administrativ-si-reprezentarea-legala-a-societatii-comercialei/, consultat în data de 25.03.2020. Autorul citat susține că însăși numirea administratorilor generează capacitatea de exercițiu a societății.

44 T. Prescure, B. TeOdoREscu, Despre natura juridică a contractului de administrare dintre o societate comercială și administratorii acesteia, extras din RRDA nr. 4/2017, p. 1, publicat online la data de 14.06.2018, la adresa https://www.universuljuridic.ro/despre-natura-juridica-a- 
Cu toate acestea, trebuie amintit faptul că în cazul acestui tip de raport, spre deosebire de reprezentarea de drept comun, cel care stabilește limitele puterii de reprezentare și cel care exercită această putere sunt, în fapt, organe ale aceleiaşi entităţi, acestea neavând o personalitate juridică distinctă de cea a societății, respectiv de cea a persoanelor fizice care le compun ${ }^{45}$. Practic, în cadrul societății operează o scindare: voința acesteia privind limitele de reprezentare, numirea sau revocarea reprezentantului se exprimă prin organul deliberativ, în timp ce exercitarea efectivă a acestei puteri de reprezentare se află în mâinile organului executiv (administrativ). Nu în ultimul rând, activitatea administratorilor nu se limitează la încheierea de acte juridice în numele și pe seama societății, ci presupune, esențialmente, și atribuții de gestiune a patrimoniului social și a societății în ansamblul ei privită ca afacere ${ }^{46}$, ceea ce implică și executarea unor acte materiale.

Toate aceste considerente au condus la numeroase discuții și controverse doctrinare cu privire la natura juridică a raportului dintre societate și reprezentanții săi. Astfel, a fost enunțată teoria existenței unui contract sui generis, diferit de cel de mandat sau de administrarea bunurilor altuia, un contract numit de administrare sau administrație ${ }^{47}$, menționat expres cel puțin ca denumire în art. $144^{\wedge} 1$ alin. (6) din Legea 31/1990. În sprijinul acestei viziuni au fost invocate toate elementele de specificitate ale acestui contact prevăzute atât în normele Codului civil

contractului-de-administrare-dintre-o-societate-comerciala-si-administratorii-acesteia/, consultat în data de 25.03.2020.

45 În același sens: O. PodAru, Actul administrativ. Repere pentru o teorie altfel, Vol. I, Ed. Hamangiu, București, 2010, p. 88.

${ }^{46}$ S. Bodu, op.cit., p. 3.

47 T. Prescure, B. TeOdorescu, op.cit., p. 5; I. SFERdian, op.cit., p. 147. 
referitoare la persoana juridică, cât şi în dispozițiile Legii 31/1990 (e.g. art. 71 L: 31/199o, Secțiunea a III-a referitoare la administrarea societății pe acțiuni), prevederi apte să creeze un regim juridic suficient de caracterizat, cu toate că regulile aplicabile acestuia sunt fracționate în mai multe acte normative.

În plus, analizând regimul juridic al administrării depline a bunurilor altuia, putem constata că atribuțiile administratorului „civil” se aseamănă până aproape de identificare cu prerogativele principiale ale administratorului societar, anume exploatarea în mod profitabil a bunurilor beneficiarului, iar art. 792 alin (3) C.civ. stipulează expres aplicabilitatea prevederilor de la administrarea bunurilor altuia oricărui caz de administrare, în situația în care actul constitutiv nu prevede reguli derogatorii.

Pentru aceste motive, considerăm că raportul juridic dintre administrator și societate este un contract special de administrare a bunurilor altuia $^{48}$. Ca atare, în ipoteza în care normele acestui contract numit sunt insuficiente, se vor aplica regulile de la administrarea bunurilor altuia în calitate de drept comun. În acelaşi timp, art. 72 din Legea 13/1990, precum și art. 209 alin. (3) C.civ. reglementează faptul că raporturile dintre administrator și societate sunt supuse, prin analogie, regulilor mandatului. În privința acestei reglementări, suntem de părere că normele contractului de mandat din dreptul civil și, implicit, cele referitoare la puterea de reprezentare se vor aplica

48 T. Prescure, B. Teodorescu, op.cit., p. 5. Autorii aduc ca argument suplimentar expunerea de motive aferentă Codului civil din Quebec privind instituţia administrării bunurilor altuia (transpusă cvasi ad litteram în Codul civil român), potrivit căreia intenția legiuitorului a fost de a crea un regim comun al administrării pentru a evita aplicarea concertată a mai multor instituții juridice unor raporturi complexe, precum cele legate de activitatea întreprinderilor. 
administrării societare în măsura în care sunt compatibile cu aceasta din urmă, însă recurgerea la analogie nu este necesară. Această aplicabilitate subsidiară reiese din caracterul de normă generală a contractului de mandat prin raportare la contractul de administrare a bunurilor altuia ${ }^{49}$.

\section{Nearătarea calitătii de reprezentant}

Astfel, în ceea ce privește ipoteza necunoașterii de către terț a calității de reprezentant a cocontractantului său, dreptul societar prevede anumite derogări de la regimul comun al reprezentării, în sensul că instituie obligativitatea înscrierii numirii administratorului în Registrul Comerțului, ca sistem de publicitate legală. Consecințele acestui fapt rezidă în imposibilitatea terţului de a se prevala de mecanismul de protecție instituit în favoarea sa pentru contractarea în necunoștință de cauză, sub condiția îndeplinirii formalităţilor de publicitate de către societate.

$\mathrm{Cu}$ alte cuvinte, dacă în ipoteza art. 1297 C.civ., terțul se poate prevala de buna sa credință în cazul în care nu a fost informat de faptul că reprezentantul acționează în numele și pe seama reprezentatului, cu consecința încheierii contractului între primii doi în calitate de părți, în ipoteza încheierii unui contract cu administratorul societar al cărui act de numire a fost publicat în Registrul Comerțului, terțul va fi ținut de această numire, fiindu-i opozabilă pentru simplul fapt că, deși prin ipoteză s-a aflat în eroare, aceasta nu mai este scuzabilă. De asemenea, după efectuarea publicităţii, orice neregularităţi ale numirii administratorului sunt inopozabile terțului care nu le-a cunoscut pe altă cale, el fiind îndreptățit să se prevaleze de eroarea sa privind validitatea și eficacitatea mandatului

49 Pentru argumente în favoarea acestei viziuni, a se vedea supra, pg. II.A.4.

\section{0}


cocontractantului său, eroare bazată tocmai pe cuprinsul registrului de publicitate.

În schimb, în cazul în care societatea nu a efectuat formalităţile de publicitate, în conformitate cu art. 54 alin. (2) din Legea 31/1990, aceasta nu va putea opune terțului numirea administratorului, mai exact statutul de reprezentant al acestuia, cu consecința încheierii contractului între terț şi administrator în nume propriu. $\mathrm{Cu}$ toate că articolul invocat nu menționează textual, considerăm că din alte dispoziții se poate desprinde o excepție de la această regulă, anume posibilitatea opunerii puterii de reprezentare față de terțul care a cunoscut pe altă cale de existența acesteia $^{50}$.

În acest sens, art. 50 din Legea societăţilor prevede, cu titlu de regulă, tocmai această ipoteză, norma fiind o aplicație a art. 22 C.civ. care se referă la opozabilitatea prin cunoaşterea exactă a realităţii în lipsa îndeplinirii formalismului, instituind în acelaşi timp obligativitatea instituirii legale a excepțiilor de la această regulă, anume a situațiilor în care cunoașterea de fapt nu suplineşte lipsa de publicitate. Mai mult decât atât, art. 54 din Legea societăților transpune în dreptul intern Directiva $68 / 151 / \mathrm{CEE}^{51}$ al cărei preambul menționează faptul că aceste norme uniformizate de protecție a terților ar trebui să limiteze cauzele de nevaliditate ale angajamentelor asumate în numele societății. Ca atare, dacă terțul cunoștea pe altă cale la momentul încheierii actului că persoana cu care contractează este

\footnotetext{
50 Pentru o opinie similară: I. SFERdiAN, op.cit., p. 140.

${ }^{51}$ Forma finală a actului după modificări și adăugiri este cea a Directivei (UE) 2017/1132 a Parlamentului European și a Consiliului din 14 iunie 2017 privind anumite aspecte ale dreptului societăților comerciale (codificare) (JO L 169 din 30.6.2017, pp. 46-127), care menține, în preambul, dispozițiile prezentate.
} 
administratorul unei societății și că, implicit, contractează în numele și pe seama acesteia, ar fi contraintuitiv și nefezabil să se lipsească de opozabilitate acea putere de reprezentare, cu atât mai mult cu cât un eventual efect constitutiv al înscrierii în Registrul Comerțului nu are nicio bază legală.

$\mathrm{Cu}$ toate acestea, a fost exprimată o părere contrară ${ }^{52}$ acestei viziuni, conform căreia depunerea specimenului de semnătură înseamnă însăşi acceptarea calității de reprezentant de către administrator. Considerăm totuşi că formalitatea depunerii specimenului de semnătură are o valență pur probatorie, instituind o prezumție în sensul validității şi eficacității puterii de reprezentare din mâinile semnatarului ${ }^{53}$, astfel că nu influențează eficacitatea mandatului în sine. Pentru aceleaşi motive, terțul va putea invoca existența puterii de reprezentare chiar dacă publicitatea nu a fost efectuată, soluție cuprinsă în art. 51 din Legea 31/1990.

3. Contractarea cu terțul după modificarea mandatului sau revocarea administratorului

În ceea ce privește încetarea mandatului administratorului, în cazul în care numirea unui nou reprezentant nu a fost publicată $\breve{a}^{54}$, terților nu le poate fi opusă o atare încetare, cu consecința obligării societății prin contractul încheiat de vechiul administrator, în conformitate cu prevederile aceluiaşi art. 54 alin. (2) din Legea societăților. Argumentele precedente privind

$5^{2}$ S. Bodu, op.cit., p. 2.

53 În același sens, a se vedea:, T. Constanța, sen.civ. nr. 2705 din 09.10.2014, consultată la adresa http://www.rolii.ro/hotarari/589ae796e49009482600012f în data de 01.04.2020.

54 Din punct de vedere practic, simpla încetare a mandatului nu va fi înregistrată fără o numire concomitentă, întrucât ar conduce la dizolvarea anticipată a societății (art. 237 din Legea 31/1990). 
cunoașterea de fapt a terțului rămân relevante. O situație controversată constituie însă ipoteza încetării puterii de reprezentare prin expirarea termenului pentru care a fost conferită şi neurmată de o nouă numire în cazul în care vechiul administrator rămâne înscris în registrele de publicitate. Divergențele au survenit, în principal, datorită faptului că legea instituie, cu caracter imperativ în anumite cazuri, limitarea duratei maxime a mandatului administratorului, precum și condiția acceptării exprese de către reprezentant a conferirii respectivei puteri (e.g. art. $153^{12}$ din Legea 31/1990). Problema a fost soluționată prin Decizia 24 din 6 noiembrie 2017 a Înaltei Curți de Casație și Justiție55, dată într-un recurs în interesul legii, formând obiectul dosarului nr. 1699/1/2017 conform căreia, în această ipoteză, vechiul administrator deține prerogativele de reprezentare atât timp cât încetarea nu a fost publicată în Registrul Comerțului. Din considerentele Curţii reiese faptul că mandatul administratorului încetează, însă devine aplicabilă situația mandatului aparent, conform art. 1309 alin. 2 C.civ.

Ca urmare a acestei decizii, a fost expusă opinia ${ }^{56}$ conform căreia, în realitate, mandatul administratorului nu încetează, întrucât ar opera excepția prevăzută în art. 2030 C.civ. referitoare la continuarea mandatului în situația unei activități cu caracter de continuitate, precum și art. 849 alin. (2) C.civ. din materia administrării bunurilor altuia, invocând deci necesitatea protecției societății aflate în prag de dizolvare datorită lipsei organelor statutare. Această perspectivă este totuși susceptibilă de a fi amendată, deoarece societatea nu își îndeplinește diligențele minime în cazul în care omite să numească un nou

55 Decizie publicată în M. Of. nr. 153/19.02.2018.

${ }^{56}$ I. SFERDIAN, op.cit., p 141-145. 
administrator la data împlinirii termenului stipulat pentru puterile vechiului reprezentant. În plus, societatea beneficiază de remedii legislative în cazul vacanței poziției de administrator (art. 137^2 din Legea societăților), astfel că nu poate beneficia de $o$ atare protecție.

În ceea ce ne privește, suntem de acord cu soluția curții, în sensul că puterea de reprezentare încetează, iar societatea rămâne legată de actele ulterioare încheiate cu terții de bună-credință, însă exprimăm serioase rezerve în privința motivării deciziei. Astfel, încetarea puterii de reprezentare nu poate fi contestată chiar în lipsa dispozițiilor imperative privind durata maximă a termenului. Chestiunile referitoare la întinderea în timp a puterii de reprezentare țin strict de raporturile dintre societate și reprezentant, astfel că la împlinirea termenului stipulat, puterea de reprezentare încetează în mod invariabil atât timp cât nu a intervenit o nouă numire urmată de o acceptare.

În acest caz, se impune protejarea terților care au contractat cu vechiul administrator sprijinindu-se pe înscrierea din Registrul Comerțului, însă nu prin recurgerea la mandatul aparent, ci prin aplicarea regulii din art. 1307 alin. (4) C.civ., regăsită în materia administrării bunurilor altuia la art. 849 alin (3) C.civ. Ca atare, terțului contractant îi va fi inopozabilă încetarea puterii de reprezentare, aflându-se în eroare scuzabilă dacă în Registrul Comerțului figurează cocontractantul său și nici nu a cunoscut pe altă cale această încetare.

Argumentarea aplicării acestor prevederi în detrimentul celor de la art 1309 alin. (2) C.civ. se regăsește în faptul că în ipoteza lipsei puterii de reprezentare, norma vizează strict cazul în care puterea respectivă nu a fost conferită niciodată, nefiind vorba de existența sa inițială și încetarea sa 
ulterioară, întrucât această situație s-ar situa pe terenul art. 1307 C.civ. ${ }^{57} \mathrm{Cu}$ alte cuvinte, în ipoteza de la art. 1309 C.civ., „reprezentantul” contractează în condiții care nu-i sunt permise şi nici nu i-au fost permise vreodată ${ }^{58}$, în timp ce situația analizată presupune o existență precedentă a puterii de reprezentare.

Astfel, distincția principală dintre cele două mijloace de protecție a terțului contractant (i.e. art. 1309 vs art. 1307 C.civ.) este faptul că primul se bazează pe teoria aparenței, iar cel de-al doilea se explică prin inopozabilitatea față de terț a puterii de reprezentare. Dar din ce motiv nu s-ar putea considera că lipsa reprezentării este inopozabilă față de terț? Răspunsul se referă la faptul că terțul nu se poate prevala de o realitate precedentă pe care să o fi cunoscut și care să prevaleze unei realități actuale întrucât nu există o asemenea realitate originară (i.e. puterea de reprezentare nu doar că nu există în prezent, dar nu a existat niciodată). Ca atare, o invocare a inopozabilității i-ar fi cu totul inutilă ${ }^{59}$, dat fiind că declararea inopozabilităţii nu poate da naştere unei puteri de reprezentare care nu a fost vreodată conferită, ci ar putea, cel mult, să ,„̂nvie” o putere care a încetat (art 1306, 1307 C.civ.) ori să permită ignorarea uneia existente (art. 1297 C.civ.). Cu toate acestea, în situația expirării mandatului administratorului puterea de reprezentare a existat în trecut, astfel că invocarea de către terț a inopozabilității față de acesta a încetării puterii îi este utilă şi suficientă pentru ca societatea să fie ținută de actele fostului administrator.

57 Pentru o părere contrară: I.F PoPA, Ipoteza falsus procurator, în RRDP nr. 2/2019., p. 194.

$5^{8}$ De aceea nu poate fi primită părerea exprimată în H. DuMITREScu, Reprezentarea, în Fl. A. Baias, E. Chelaru, R. Constantinovici, I. Macovei, op.cit., p. 1457 conform căreia art. 2036 C.civ. ar fi aplicabil și în această situație.

59 M. DAVID, Eseu asupra cunoașterii în dreptul civil. Aparență. Opozabilitate. Formalism. Publicitate, Ed. Universul Juridic, București, 2017. p. 181. 
Toate aceste prevederi de protecție a terţilor prin instituirea obligativității de efectuare a publicității se justifică prin prisma faptului că în acest caz reprezentatul și reprezentantul formează o entitate de sine stătătoare a căror raporturi interne nu pot fi cunoscute de terți. Aceștia nu au acces în interiorul societății pentru a verifica raporturile dintre administrator şi societate, astfel că singurul mijloc de informare cu privire la aceste operațiuni rămâne Registrul Comerțului ${ }^{60}$.

4. Lipsa sau depășirea puterii de reprezentare

O altă ipoteză care se cuvine a fi supusă analizei este cea a reprezentantului aparent, adică a celui ce contractează cu un terț fără a fi fost numit în funcția de administrator de către societate. În acest caz, dat fiind că reglementările aferente administrării bunurilor altuia nu rezolvă această situație, considerăm că devin aplicabile prevederile art. 1309 C.civ. Totuşi, aplicabilitatea practică a acestei chestiuni este extrem de redusă întrucât personalul din cadrul Oficiului Registrul Comerțului nu va efectua înscrierea ca administrator a unei persoane fără documente doveditoare privind numirea acesteia.

În schimb, situația depăşirii puterii de reprezentare de către administratorul societar este reglementată fără echivoc în art. 55 al Legii 31/1990. Astfel, actul încheiat de administrator prin depăşirea obiectului de activitate al societății sau a limitelor trasate în cadrul raporturilor sale cu societatea, va fi încheiat în numele și pe seama celei din urmă. Aceeași

${ }^{60}$ L. TEc, Examenul jurisprudenței în materia reprezentării societății și răspunderii civile a administratorilor față de societate, extras din RRDA nr. 4/2016, publicat online la data de 09.11.2017 la adresa https://www.universuljuridic.ro/examenul-jurisprudentei-materia-reprezentariisocietatii-si-raspunderii-civile-administratorilor-fata-de-societate/2/, adresă consultată în data de 02.04.2020. 
va fi soluția și în cazul în care administratorul contractează în limitele conferite printr-o adunare generală a acționarilor/asociaților anulată ulterior $^{61}$. De la această regulă există două excepții, anume ipoteza în care limitele respective sunt impuse de lege, caz în care se aplică principiul nemo censetur ignorare legem, respectiv cunoașterea sau posibilitatea cunoaşterii de către terț a depăşirii limitelor reprezentării. În vederea acestui ultim caz, legea prevede în mod expres că simpla publicare a actului constitutiv ori a altui act prin care se limitează puterile nu e suficientă pentru a înlătura caracterul scuzabil al erorii terțului.

Pe cale de consecință, legiuitorul renunţă la efectele publicităţii asupra bunei-credințe a terțului, optând pentru o cunoaștere efectivă, respectiv posibilitatea unei cunoașteri efective, independente de publicitate. $\mathrm{Cu}$ alte cuvinte, societății nu îi va fi suficient să probeze publicarea limitării, ci va trebui să dovedească, în plus, verificarea efectivă de către terț a registrului sau faptul că a aflat ori putea afla pe altă cale. Această soluție e justificată de faptul că activitatea unei întreprinderi poate fi foarte prolifică, iar obligarea terților de a studia în permanență actul constitutiv şi deciziile organelor deliberative ar fi abuzivă. Se remarcă astfel sporirea protecţiei conferită terțului în această ipoteză. Spre deosebire de dreptul comun al mandatului aparent, reglementat la art. 1309 alin. (2), respectiv la art. 817 C.civ., în cazul depăşirii puterilor de reprezentare de către administratorul societar nu se mai cere ca eroarea în care se află terțul să fie provocată de comportamentul reprezentatului.

Astfel, raportul dintre administrator şi societate se prezintă sub forma unui contract special de administrare a bunurilor altuia, ale cărui dispoziții

\footnotetext{
${ }^{61}$ Pentru comentariul critic al anumitor soluţii jurisprudențiale contrare, a se vedea: L. TEC, op.cit., p. 1.
} 
privitoare la puterea de reprezentare conțin derogări de la dreptul comun, acestea fiind în concordanță cu modul specific de exercitare a capacității de exercițiu aferent acestui subiect de drept.

\section{Concluzii}

Ne-am propus să punem față în față a unele opinii doctrinare, cel puțin parțial contradictorii şi să prezentăm o perspectivă proprie prin raportare la acestea, respectiv la normele legale aplicabile. Prin argumentele expuse și discuțiile prezentate, am încercat să răspundem întrebărilor preliminare, creionând astfel o concepție proprie cu privire la anumite subiecte de interes aferente puterii de reprezentare.

Astfel, ne-am îndreptat întâi atenția asupra puterii, ca prerogativă, în calitate de gen al puterii de reprezentare. În acest sens, am încercat să argumentăm faptul că puterea este o legătură între persoane care impune anumite îndatoriri inerente beneficiarului ei, fiind apte de a genera sancțiuni specifice. Am constatat, în acest sens, cum că una dintre aceste îndatoriri se referă la faptul că acela care dobândește puterea se vede nevoit să acționeze măcar parțial în interesul celui care i-a conferit (iar nu transmis) această prerogativă.

Intrând în miezul discuției, am stabilit cum se comportă puterea de reprezentare în ecosistemul dreptului civil, concluzionând în sensul că nu derogă de la principiul relativității efectelor contractului, ci discuția se poartă pe terenul conferirii puterii şi al jocului dintre consimţămintele reprezentantului şi al celui reprezentat. În acest sens, am analizat în mod critic o opinie originală, însă lipsită de pragmatism, conform căreia există o separare între consimțământul dat la încheierea contractului de mandat și cel

\section{8}


dat (prin act unilateral) la conferirea puterii de reprezentare, părere la care nu am aderat.

În ceea ce privește aria de acoperire a puterii de reprezentare, ne-am opus fără echivoc tendințelor de extindere a obiectului la faptele juridice sau actele materiale, rămânând fideli concepției clasice referitoare la încheierea actelor juridice prin reprezentant, ca unică ipoteză admisibilă. În fine, am încercat să înlăturăm orice fel de confuzii între reprezentare și alte instituții aparent similare, context în care ne-am distanțat de păreri conform cărora ar exista alte mecanisme care, fără a conferi putere de reprezentare, ar fi apte de aceleaşi efecte ori de opinii care susțin caracterul de drept comun în materie de reprezentare al controversatului contract de administrare a bunului altuia.

Nu în ultimul rând, în urma efectuării unei paralele între mandatul administratorului unei societăți şi cel de drept comun, am conchis în sensul existenței unei relații de la general la special între cele două, mai cu seamă datorită admiterii existenței unui contract sui generis de administrare sau administrație care funcționează exclusiv în raporturile dintre administrator şi societate. În acest context am relevat elementele derogatorii ale acestui tip de reprezentare, observând faptul că sursa diferențelor este Registrul Comerțului, ca sistem de publicitate legală. Ca atare, dat fiind caracterul eclectic al „mandatului legal” exercitat de administratorul societăţii, o înțelegere deplină a puterii de reprezentare în acest context necesită cunoașterea dreptului comun în materie, precum și realitățile la care se pliază: specificul dreptului societar, un sistem esențialmente pragmatic și necesitățile sale.

Pe cale de consecință, fără a mai insista asupra importanței incontestabile a mecanismului reprezentării în realitatea juridică actuală, subliniem că aceasta este o veritabilă putere demnă de a fi înțeleasă și utilizată 
în deplina sa complexitate, cu perspectiva adaptării sale la evoluțiile viitoare ale domeniului juridic și economic deopotrivă. 